\title{
Pemetaan Cepat Kawasan Terdampak Bencana Longsor dan Banjir di Kabupaten Bangli, Provinsi Bali
}

\author{
Theresia Retno Wulan ${ }^{1,3}$, Wiwin Ambarwulan', Anggara S. Putra ${ }^{4}$, Farid Ibrahim², Mega D. Putra ${ }^{2}$, \\ Dwi Maryanto $^{1}$, Ferrari Pinem ${ }^{1}$, dan Edwin Maulana ${ }^{2}$
}

Badan Informasi Geospasial ${ }^{1,}$ Indonesia

Parangtritis Geomaritime Science Park ${ }^{2}$, Yogyakarta, Indonesia

Program Doktoral, Fakultas Geografi, Universitas Gadjah Mada, Yogyakarta, Indonesia ${ }^{3}$

Statistika, Universitas Islam Indonesia, Indonesia ${ }^{4}$

Email Koresponden :theresia.retno@big.go.id

Diterima : Juni 2017 ; Direvisi : Juli 2017; Dipubikasikan: September 2017

( 2017 Fakultas Geografi UGM dan Ikatan Geograf Indonesia.

\begin{abstract}
Abstrak Teknologi penginderaan jauh mengalami perkembangan yang sangat pesat. Salah satunya adalah teknologi akuisisi data dengan menggunakan UAV (Unmanned Aerial Vehicle). Teknologi UAV dapat dipergunakan dalam berbagai bidang, salah satunya adalah bidang kebencanaan. Tujuan penelitian ini adalah untuk melakukan pemetaan secara cepat kawasan terdampak bencana banjir dan longsor di Kabupaten Bangli, Bali dengan menggunakan teknologi UAV. Metode yang digunakan adalah pemotretan udara dengan UAV, survei lapangan dan analisis laboratorium. Pemotretan udara dilakukan satu hari pasca kejadian longsor dengan ketinggian jelajah pesawat antara 100-120 meter di atas permukaan tanah. Resolusi spasial yang dihasilkan antara 4,5-6,5 cm. Wilayah yang berhasil dipetakan adalah wilayah yang terdampak banjir dan longsor di Desa Songan A serta Songan B, wilayah terdampak banjir bandang Yeh Mampeh di Desa Batur Selatan, serta wilayah terdampak longsor di Desa Sukawana dan Desa Awan. Berdasarkan hasil pemotretan udara, dapat diketahui luasan daerah terdampak longsor. Lebih lanjut, strategi rehabilitasi dan rekonstruksi dapat dilakukan dengan menggunakan hasil pemotretan udara.
\end{abstract}

Kata kunci: UAV, Rapid Mapping, banjir, longsor, Bali

Abstract Remote sensing technology is experiencing rapid developments. One of which is in the field of data acquisition that has currently adopted the use of Unmanned Aerial Vehicle (UAV). UAV technology is, for instance, employed in various studies related to disasters. This research aimed to perform a rapid mapping of flood-and landslide-affected areas in Bangli Regency, Bali using UAV technology. The applied methods included UAV-assisted aerial photography, field survey, and laboratory analysis. The aerial photography was conducted one day after the landslide event and at a recording altitude of 100-120 $\mathrm{m}$ above the ground. The spatial resolution produced in the photography was $4.5-6.5 \mathrm{~cm}$. The mapped areas were the ones affected by floods and landslides in Songa A and Songa B Villages, flash floods in Yeh Mampeh, Batur Selatan Village, and landslides in Sukawana and Awan Villages. The aerial photography also provided the extent of the landslide-affected areas. Therefore, the post-disaster rehabilitation and reconstruction strategies can be implemented using the results of the aerial photography.

Keywords: UAV, Rapid Mapping, Flood, Landslide, Bali

\section{PENDAHULUAN}

Penginderaan jauh merupakan salah satu metode yang dipergunakan dalam berbagai disiplin ilmu (Amir et al., 2017; Rozenstein dan Adamowski, 2017; Andres et al., 2017; Rhee dan Im, 2017; Djomo dan Chimi, 2017; Taubenbock et al., 2017; Guo et al., 2017). Hal ini dikarenakan pemanfaatan penginderaan jauh memberikan banyak keuntungan dan kemudahan untuk menganalisis berbagai hal. Pemanfaatan metode penginderaan jauh untuk bidang kebumian, semakin berkembang pesat dengan adanya teknologi Unmanned Aerial Vehicle (UAV) (Trigueros et al., 2017; Maulana dan Wulan, 2015a; Bemis et al., 2014).

Unmanned Aerial Vehicle (Gambar 1) adalah teknologi pesawat tanpa awak yang dilengkapi dengan sensor dan kamera untuk melakukan pengambilan gambar (Marfai et al., 2014a). Hasil pengambilan gambar dengan menggunakan UAV nantinya akan diolah menjadi foto udara yang dapat dipergunakan untuk pemetaan dan analisis lainya (Fotogrametri) (Purwanto, 2017). Pemanfaatan teknologi UAV juga dapat dipergunakan untuk analisis kebencanaan (Niethammer et al., 2012; Stumpf et al., 2013, Marfai dkk., 2014b; Masruroh, dkk., 2016; Neugirg et al., 2016; Vetrivel et al., 2017; Pineux et al., 2017). 


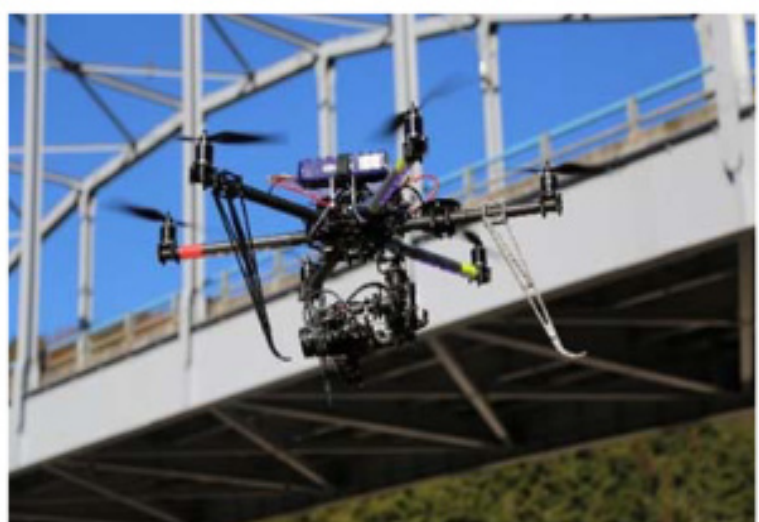

Gambar 1. Contoh UAV

(Watanabe and Kawahara, 2016)

Secara umum, UAV dapat dibagi menjadi 2 (dua) tipe, yakni UAV tipe fixed wing dan tipe rotor. Kedua tipe UAV ini mempuyai kelebihan dan kekurangan masing-masing. seperti UAV dengan tipe fixed wings memiliki kelebihan pada luas daerah jelajah, namun memerlukan daerah yang cukup luas dan datar untuk take off maupun landing. Kondisi berbeda ada pada UAV dengan tipe rotor yang memiliki kemampuan untuk hover (berhenti di udara) dan dapat diterbangkan dalam segala medan karena tidak memerlukan lokasi yang luas untuk take off maupun landing, namun luas daerah jelajah UAV tipe ini lebih sempit dibandingkan dengan tipe fixed wing. Baik tipe rotor maupun fixed wing, data yang diperoleh dapat dipergunakan untuk melakukan pemetaan, atau yang kita kenal dengan teknik fotogrametri.

Teknologi UAV dapat dipergunakan secara mudah dan efisien dari segi waktu. Data yang diperoleh juga memiliki resolusi spasial yang tinggi, sehingga kesalahan dalam identifikasi objek atau pengukuran suatu objek di lapangan dapat diminimalisir. Penggunaan teknologi UAV dapat memudahkan pengguna mengidentifikasi objek yang sulit dijangkau. Pemanfaatan UAV di bidang kebencanaan dapat dilakukan secara cepat dan efisien, sehingga teknologi UAV sangat tepat untuk dipergunakan dalam pemetaan cepat.

Tujuan dari kajian ini adalah untuk melakukan pemetaan cepat (Rapid Mapping) dengan menggunakan teknologi UAV tipe rotor (quadcopter) pada kawasan terdampak bencana di Kabupaten Bangli, Provinsi Bali, sehingga pengambilan keputusan dalam rangka menjalankan tahapan penanganan bencana dapat dilakukan dengan baik.

\section{METODE PENELITIAN \\ Instrumen UAV}

Sumber data yang dipergunakan dalam kajian ini adalah data primer dari hasil pemotretan dengan menggunakan wahana UAV. UAV yang dipergunakan adalah UAV tipe multirotor (quadcopter). Teknologi UAV yang digunakan dalam penelitian ini ditunjukkan oleh Gambar 2, sedangkan spesifikasinya ditunjukkan oleh Tabel 1.

UAV yang digunakan dalam penelitian ini adalah UAV generasi keempat yang telah dilengkapi dengan spesifikasi mumpuni dibandingkan tipe-tipe sebelumnya. Salah satu spesifikasi yang terpasang pada UAV ini adalah adanya sensor depan. Hal ini memungkinkan UAV dapat menghindar apabila ada obstacle di hadapanya.

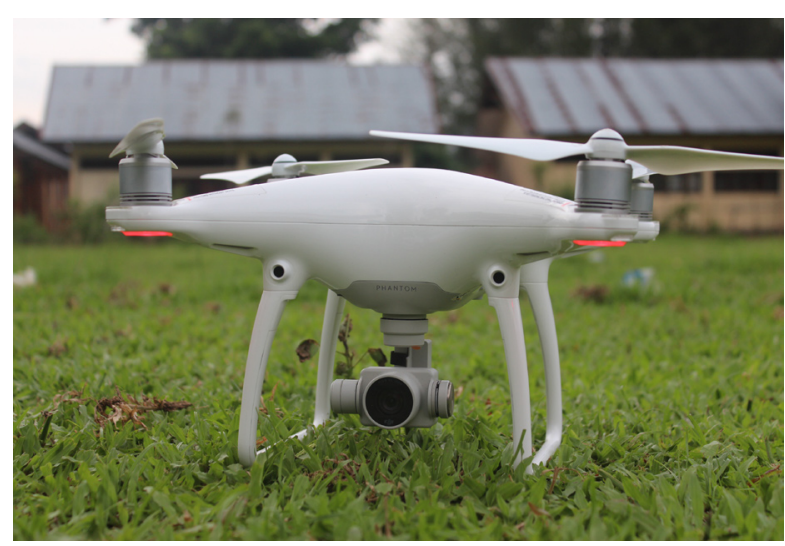

Gambar 2. Teknologi UAV Tipe Rotor (Quadcopter) Yang Digunakan dalam Penelitian

Tabel 1. Spesifikasi UAV dan Kamera yang Digunakan Dalam Penelitian

\begin{tabular}{ll|ll}
\hline \multicolumn{2}{c}{ Spesifikasi UAV } & \multicolumn{2}{c}{ Spesifikasi Kamera } \\
\hline Tipe & $\begin{array}{l}\text { Quadcopter } \\
\text { 1.380 gram (termasuk baling- } \\
\text { baling dan baterai) }\end{array}$ & Sensor & CMOS 1/2.3” \\
Berat & $20 \mathrm{~m} / \mathrm{s}$ & Resolusi & FOV 940 20mm \\
Kecepatan & 28 menit & Resolusi foto & 12.4 MP \\
Durasi Terbang & Intelligent Flight Battery 81.3 & Format foto & JPEG, DNG (RAW) \\
Energi /Voltage & Wh / 15.2 V & & $100-1600$ (Photo); \\
Jarak Transmisi & $3.5 \mathrm{~km}$ & ISO & $100-3200$ (Video) \\
remote kontrol & & & \\
\hline
\end{tabular}

Sumber : http://www.dji.com/phantom-4/info\#specs 


\section{Deskripsi Wilayah Kajian}

Kabupaten Bangli, adalah salah satu Kabupaten yang berada di Provinsi Bali. Kabupaten Bangli terbagi menjadi 4 (empat) kecamatan. Keempat kecamatan tersebut adalah Kecamatan Kintamani, Kecamatan Susut, Kecamatan Tembuku dan Kecamatan Bangli. Kondisi fisiografis Kabupaten Bangli sebagian besar merupakan daerah pegunungan, karena bersinggungan dengan kawasan Gunungapi Batur.

Kecamatan Kintamani, merupakan Kecamatan dengan jumlah Desa terbanyak di Provinsi Bali, yakni 48 Desa. Luas Kecamatan Kintamani adalah 366,9 Km2 (BPS, 2016). Enam desa yang terdapat di Kecamatan Kintamani memiliki nilai Indeks Kesulitan Geografis (IKG) tertinggi yakni Desa Binyan, Mengani, Ulian, Langgahan, Banua, Abuan (BPS, 2016). Secara sederhana lokasi kajian, yakni Kecamatan Kintamani dapat diamati pada Gambar 3.

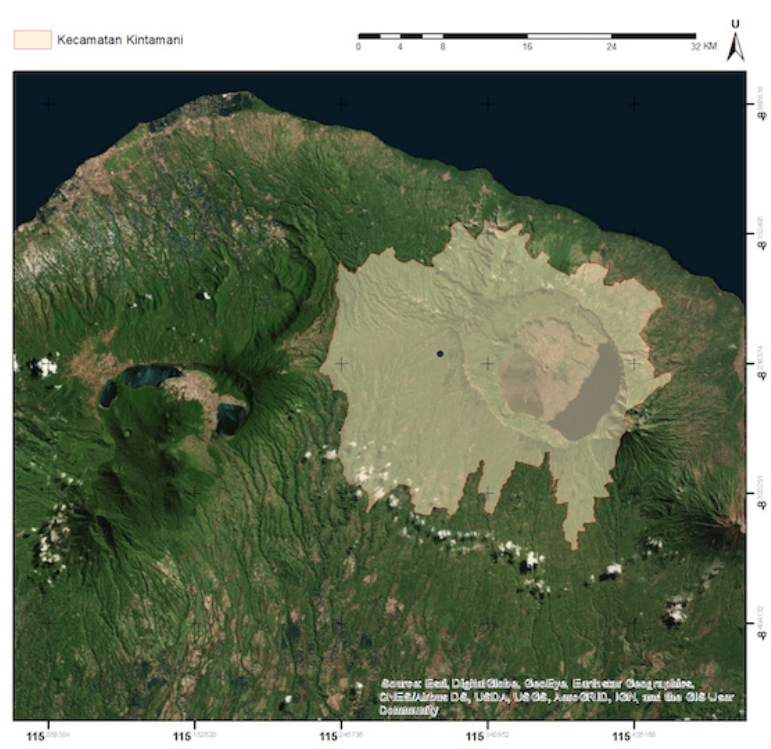

Gambar 3. Peta Citra Kecamatan Kintamani

\section{Akuisisi Data Foto Udara}

Pemotretan udara kawasan terdampak bencana di Kecamatan Kintamani dilakukan dengan menggunakan wahana Unmanned Aerial Vehicle (UAV) tipe multirotor (quadcopter). Wahana tipe multirotor ini dipilih untuk menyesuaikan kondisi medan yang berbukit dan bertebing. Teknologi UAV tipe multirotor dapat diterbangkan tanpa membutuhkan areal luas untuk lepas landas maupun landing. Secara sederhana, tahapan uji akuisisi data yang dilakukan dapat diamati pada Gambar 4.

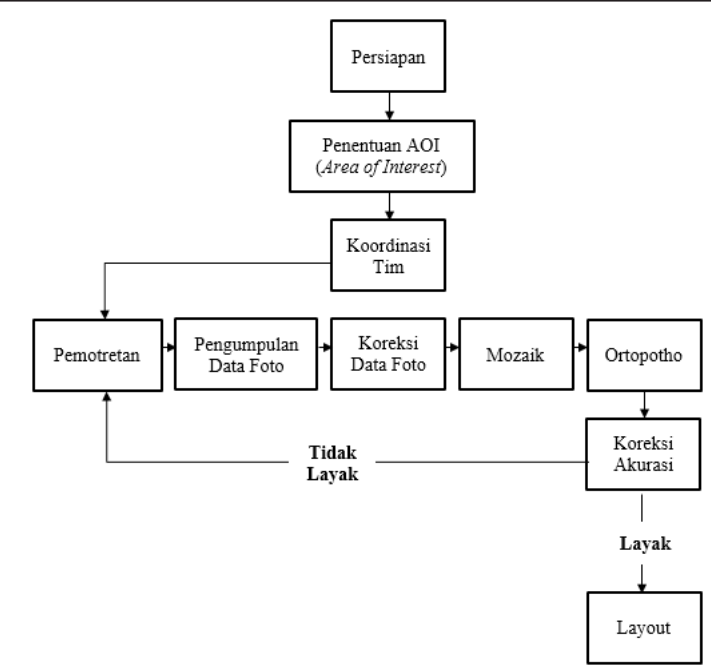

Gambar 4. Diagram Alir Akuisisi Data dengan UAV (Putra dkk., 2016)

\section{HASIL DAN PEMBAHASAN}

\section{Hasil Uji Akuisisi Foto Udara Kawasan Terdampak Longsor}

Pemotretan udara dilakukan pada tanggal 12 Februari 2017. Terdapat 5 (lima) Desa yang menjadi area pemotretan, yakni Desa Songan A, Songan B, Yeh Mampeh, Sukawana, dan Awan. Penentuan kelima desa tersebut merupakan hasil dari Satuan Reaksi Cepat (SRC), Badan Penanggulangan Bencana Daerah (BPBD) Provinsi Bali dan Pusat Pengendalian Pembangunan Ekoregion (PPPE) Bali - Nusa Tenggara. Pemotretan dilakukan dengan ketinggian berbeda di setiap lokasi untuk menyesuaikan kondisi lokasi yang berbukit -bukit (Tabel 2). Hasil pemotretan kemudian dilakukan proses pengolahan berupa mosaic foto udara, maka didapatkan ortophoto dan kemudian dijadikan dasar sebagai layout peta citra.

Tabel 2. Resolusi dan Ketinggian jelajah

\begin{tabular}{lcc}
\hline \multicolumn{1}{c}{ Desa } & Resolusi $(\mathrm{cm})$ & Ketinggian $(\mathrm{m})$ \\
\hline Songan B & 4.5 & 120 \\
Songan A & 5.1 & 100 \\
Songan A & 6.5 & 150 \\
Yah Mampeh & 4.5 & 120 \\
Sukawana & 5.1 & 100 \\
Awan & 5.5 & 120 \\
\hline
\end{tabular}

Sumber: Kegiatan Lapangan (2017)

\section{Survei Cepat Kawasan Terdampak Longsor}

Pemotretan pertama dilakukan di Desa Songan B tepatnya di Dusun Banjar Bantas. Bencana di titik ini termasuk dalam kategori bencana longsor dengan jumlah korban jiwa 7 orang dan 5 rumah rusak berat. Kejadian longsor terjadi pada tanggal 10 Februari 2017 01:00 WITA. Selain disebabkan curah hujan yang 
tinggi di dua hari sebelumnya, secara topografi lokasi ini berada pada kelas lereng sangat curam (>40\%). Hal ini diperparah dengan tutupan lahan di sekitar lokasi longsor berupa pertanian musiman seperti bawang dan tomat. Akar tanaman musiman umumnya serabut, sehingga kurang maksimal dalam mencegah erosi. Akibatnya, volume tanah yang mengalami transportasi akan semakin besar dan meningkatkan beban di atas bidang gelincir. Berdasarkan hasil interpretasi foto udara (Gambar 5), kejadian longsor dipengaruhi oleh struktur jalan yang berkelok dan curam. Jalan yang berkelok menyebabkan kemungkinan aliran permukaan dari air hujan akan terpusat pada titik tertentu. Kondisi jalan yang curam menyebabkan volume air yang terkumpul cukup banyak dalam waktu yang singkat. Selanjutnya, aliran permukaan akan meresap ke dalam tanah dan mempengaruhi bidang gelincir. Jenuhnya tanah oleh air akan menyebabkan kestabilan tanah terganggu (dipadukan dengan faktor kemiringan lereng) dan menyebabkan terjadinya longsor.

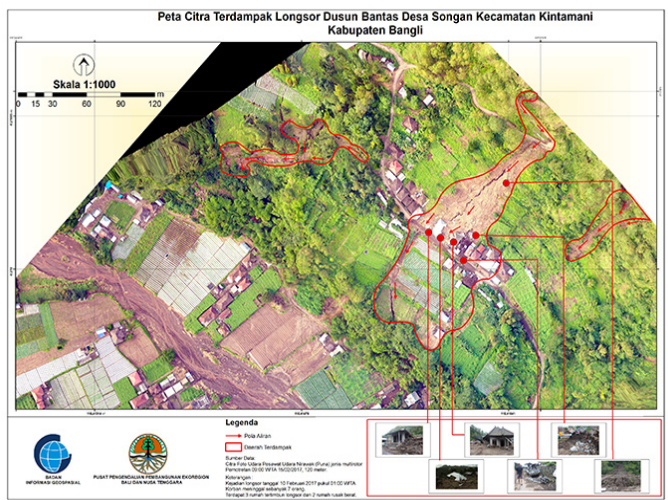

Gambar 5. Peta Citra Terdampak Longsor di Desa Songan B

Pemotretan udara kedua terletak di Desa Songan A, Kecamatan Kintamani (Gambar 6). Secara morfologi daerah ini merupakan dataran banjir dan delta dengan kelas kemiringan lereng datar (0-8\%), dan merupakan daerah muara sungai yang terletak di sebelah utara Danau Batur. Penggunaan lahan didominasi penggunaan lahan untuk pertanian dan permukiman.

Bencana sekunder dari tanah longsor adalah bencana banjir bandang (Maulana dan Wulan, 2015b). Dalam waktu yang bersamaan dengan kejadian longsor di Desa Songan B, air beserta material tanah dan vegetasi dalam debit yang besar menyapu daerah terdampak ini. Air beserta material tersebut berasal dari salah satu daerah tangkapan air (DTA) Danau Batur yang mengalir melalui sungai intermiten. Daerah tangkapan air dengan luas 1.814,6 ha ini meliputi sebagian desa Sukawana, Belandingan dan Pinggan. Besarnya debit air ini selain akibat curah hujan dengan intensitas tinggi dan durasi yang lama, juga disebabkan oleh penggunaan lahan pertanian semusim, dan sebagian menggunakan plastik/mulsa yang meningkatkan jumlah aliran permukaan. Kerugian yang diakibatkan terutama kerusakan lahan pertanian di sekitar sungai, namun tidak ada korban jiwa maupun rumah yang rusak berat.

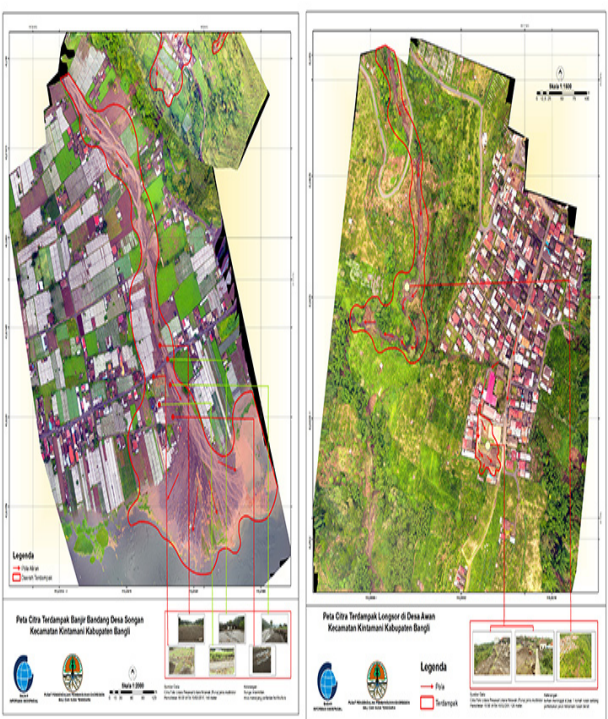

Gambar 6. Peta Citra terdampak Banjir Bandang di Titik Pertama Desa Songan A

Pemotretan ketiga berada di Desa Songan A (Gambar 7), satu desa dengan titik keduan namun berada di area yang terpisah. Daerah ini merupakan daerah terdampak bencana banjir bandang. Hasil interpretasi data foto udara dan survei lapangan mengidentifikasi setidaknya terdapat 12 rumah yang terendam dan tertimbun material dengan kedalaman sekitar $60 \mathrm{~cm}$. Tidak ada korban jiwa dalam bencana yang terjadi di kawasan ini. Namun demikian, bangunan rumah dan berbagai lahan perkebunan seperti lahan perkebunan tomat, labu siam, bunga kenikir, dan bawang merah mengalami kerusakan karena tertimbun material.

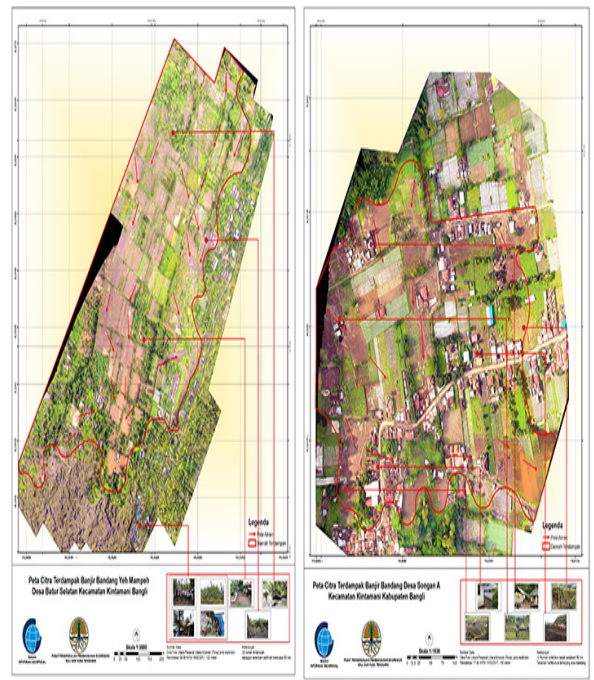

Gambar 7. Peta Citra terdampak Banjir Bandang di Titik Kedua Desa Songan A

https://jurnal.ugm.ac.id/mgi |47 
Kondisi jalan lokal yang menghubungkan permukiman juga mengalami kerusakan, sehingga mengganggu mobilitas warga, khususnya untuk aktivitas pertanian. Banjir bandang yang ada di Desa Songan A disebabkan karena alih fungsi penggunaan lahan yang ada di wilayah hulunya. Penggunaan lahan di bagian hulu Desa Songan A didominasi oleh kawasan pertanian tanaman semusim. Diperkirakan erosi yang terjadi akan meningkat secara signifikan karena akar serabut yang kurang baik untuk menahan erosi. Selain itu, teknik penanaman tanaman yang tegak lurus dengan garis kontur akan memperbesar erosi yang terjadi. Penggunaan mulsa dan plastik juga meningkatkan jumlah air limpasan, sehingga di pada saat terjadi hujan yang lebat akan memicu terjadinya longsor, disertai air dan material yang merendam rumah warga.

Desa terdampak bencana lain yang dikaji adalah Desa Yeh Mampeh (Gambar 8). Bencana yang terjadi di Yeh Mampeh adalah banjir bandang. Pemotretan di daerah terdampak di lakukan dua kali karena cakupan area (areal cover) yang luas. Banjir bandang yang melanda Desa Yeh Mampeh berdasarkan interpretasi foto udara hasil pemotretan terjadi akibat limpasan aliran permukaan dan material erosi dari bagian hulu yang berada di atas tebing dengan tinggi $+200 \mathrm{~m}$. Limpasan material mengalir melewati drainase kawasan pertanian. Oleh karena kapasitas drainase tidak mampu menampung derasnya debit aliran, limpasan material meluap hingga lahan pertanian dan permukiman. Lahan pertanian yang terdampak banjir bandang berupa tanaman holtikultura seperti labu siam, bunga kenikir, tomat, kubis dan cabai. Selain itu, material banjir juga mengakibatkan 32 rumah penduduk terendam air dan tertimbun tanah $+60 \mathrm{~cm}$. Kondisi demikian menyebabkan penduduk harus diungsikan. Beberapa titik di desa Yah Mampeh merupakan lokasi penambangan pasir, sehingga memicu penggerusan lahan yang merusak infrastruktur jalan serta lahan pertanian. Secara topografis, Desa Yeh Mampeh berada di antara kubah Gunungapi Batur Muda yang berada di sebelah timur, dengan dinding kaldera Gunungapi Batur purba di sebelah barat serta padang lava di sebelah selatan, sehingga menyebabkan daerah ini menjadi areal genangan air apabila terjadi banjir dari bagian hulu. Kondisi topografi yang demikian menjadi pertimbangan relokasi permukiman warga Desa Yeh Mampeh.
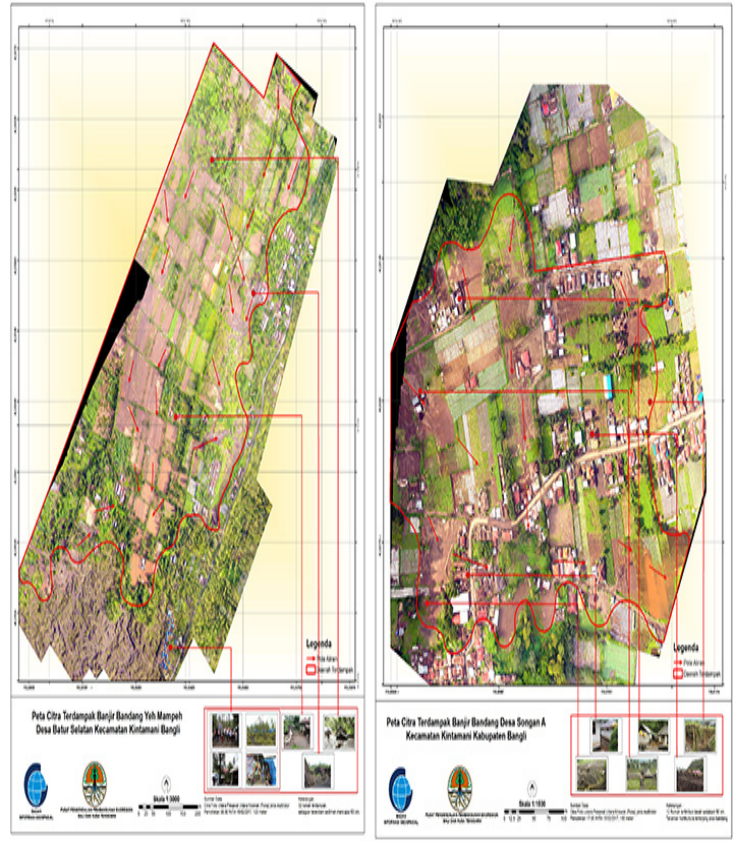

\section{Gambar 8. Peta Citra terdampak Banjir Bandang} di Desa Yeh Mampeh

Pemotretan keempat dilakukan di Desa Sukawana. Desa Sukawana memiliki curah hujan yang tinggi karena berada di daerah tertingi di Kecamatan Kintamani. Kemiringan lereng Desa Sukawana juga beragam, mulai dari agak curam hingga sangat curam. Selain itu, kerentanan gerakan tanah juga termasuk dalam kategori menengah hingga tinggi. Hal demikian yang menyebabkan Sukawana sangat berpotensi terjadi longsor. Bencana longsor di Desa Sukawana terjadi pada tanggal 10 Februari 2017, dini hari.

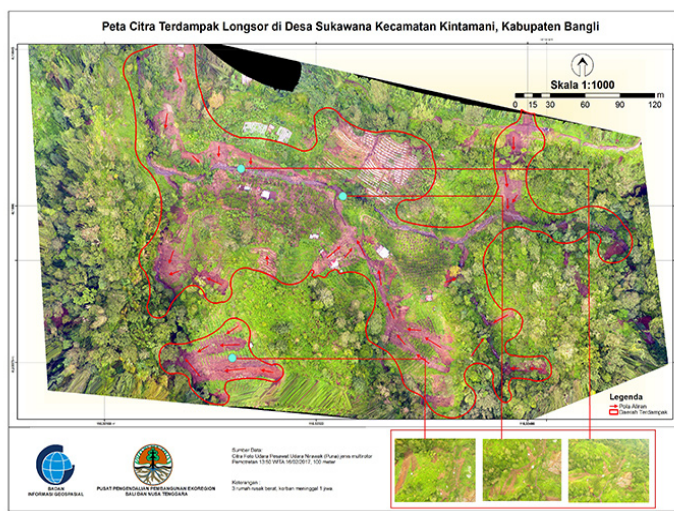

Gambar 9. Peta Citra terdampak Longsor di Desa Sukawana

Longsor ini merupakan longsor pertama kali yang terjadi di Desa Sukawana. Longsor terjadi akibat curah hujan dengan intensitas yang tinggi dengan durasi yang lama dalam beberapa hari terakhir. Untuk menuju lokasi longsor, diperlukan waktu yang cukup lama, karena lokasi longsor berada di dasar lembah. Beberapa 
ruas jalan juga terputus akibat longsoran. Longsor menyebabkan satu orang meninggal, tiga rumah rusak berat dan kerusakan lahan perkebunan seperti jeruk dan kopi.

Lokasi pemotretan kelima adalah di Desa Awan. Desa Awan berjarak $9 \mathrm{~km}$ dari Desa Sukawana, desa sebelumnya yang menjadi lokasi pemotretan. Di Desa Awan terdapat dua titik longsor yang dapat dipetakan oleh tim SRC. Lokasi titik pertama yaitu longsor yang terjadi di areal perkebunan jeruk, yang juga merupakan tutupan lahan dominan di Desa Awan. Kemudian titik kedua, longsor terjadi di areal permukiman warga.

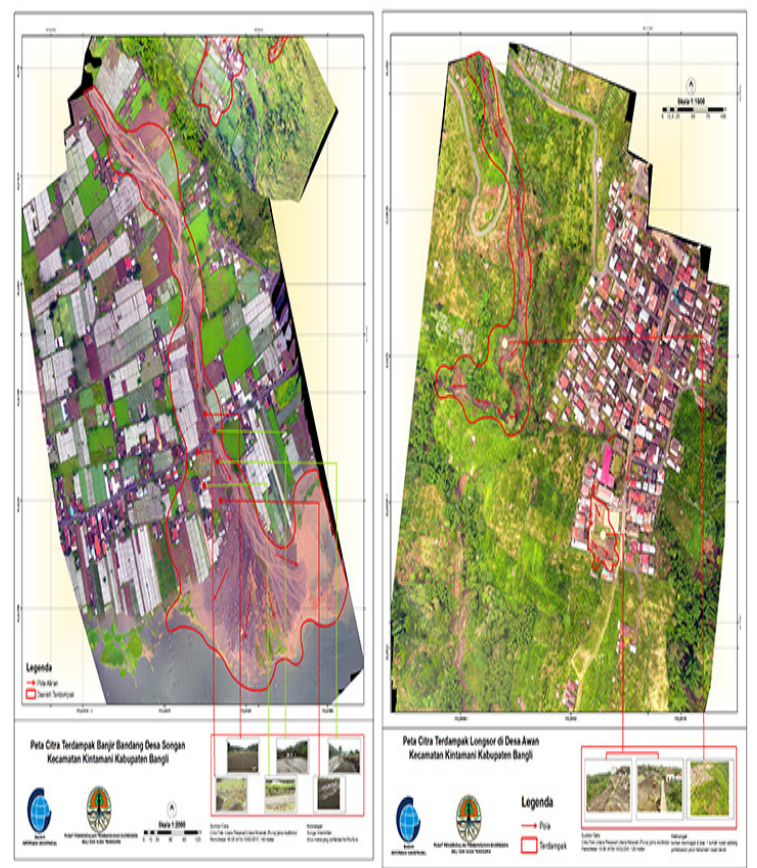

Gambar 10. Peta Citra terdampak Longsor di Desa Awan

Berdasarkan interpretasi foto udara hasil pemotretan, titik longsor pertama yang berada di areal perkebunan jeruk disebabkan oleh tingkat kemiringan lereng termasuk curam. Selain itu, intensitas hujan dalam beberapa hari terakhir mengguyur Desa Awan menyebabkan tanah yang berada pada lereng jenuh dan mengalami longsor. Intepretasi titik kedua, longsor disebabkan oleh adanya konsentrasi aliran permukaan yang dipengaruhi oleh lahan terbangun berupa jalan paving dan aspal pada kondisi lereng yang cukup curam. Air permukaan akibat curah hujan yang tinggi mengalir mengikuti ruas jalan hingga berkumpul di tanah lapang, yang berada di atas titik longsor ke dua. Air yang terkumpul kemudian meresap melalui pondasi pekarangan. Aliran air menggerus fondasi hingga menyebabkan fondasi roboh dan menimpa rumah yang berada di bawahnya. Lokasi titik pertama tidak menimbulkan korban dan hanya terjadi kerusakan di areal perkebunan jeruk. Kondisi berbeda terjadi pada titik kedua, di mana kejadian longsor menyebabkan empat orang meninggal dan satu rumah rusak.

\section{KESIMPULAN}

Wahana UAV dapat dipergunakan untuk melakukan pemetaan cepat (rapid mapping) bencana alam, karena memiliki banyak kelebihan. Salah satu kelebihan dari teknologi UAV adalah dapat diperguanakan di berbagai medan, efisien waktu dan biaya. Berbagai bencana yang telah terjadi selain disebabkan oleh faktor topografi dan iklim, salah satu hal yang memicu terjadinya bencana adalah faktor antropogenik (aktifitas manusia). Berdasarkan hasil analisis yang dilakukan, faktor antropogenik merupakan faktor yang paling dapat dikendalikan untuk mengurangi risiko bencana. Hal ini mendorong perlunya peningkatan kesadaran masyarakat akan bencana alam. Selain itu, seluruh pemangku kepentingan terkait kebencanaan dan lingkungan hidup perlu bersinergi agar risiko bencana dapat diminimalisir.

\section{UCAPAN TERIMAKASIH}

Ucapan terima kasih dihaturkan kepada BIG, BPBD dan PPPE Bali - Nusa Tenggara. Ucapan terima kasih juga disampaikan kepada penduduk di lokasi penelitian dan masyarakat yang menjadi narasumber dalam penentuan AoI.

\section{DAFTAR PUSTAKA}

Amir, O., Tuvia, B., Jean, M.W., Jorge S., Daniel B., Aharon, A., \& William T.A. (2017). Evaluation of remote dielectric sensing (ReDS) technologyguided therapy for decreasing heart failure re-hospitalizations. International Journal of Cardiology, 240, 279 - 284.

Andres, S., Damien A., Isabelle M., Therese L., \& Laurent D. (2017). Ontology-based classification of remote sensing images using spectral rules. Journal of Computer \& Geosciences, 102, 158 166.

Badan Pusat Statistik. (2016). Kabupaten Bangli Dalam Infografis 2016. Bangli: BPS Kabupaten Bangli.

Bemis, S.P., Steven M., Darren T., Mike R.J., Sinan A., Sam T.T., \& Hasnain, A.B. (2014). Groundbased and UAV-Based photogrammetry: A multi-scale, high-resolution mapping tool for structural geology and paleoseismology. Journal of Structural Geology, 69, 163 - 178.

Djomo, A.N. \& Cedric, D.C. (2017). Tree allometric equations for estimation of above, below and total biomass in a tropical moist forest: Case study with application to remote sensing. Journal of Forest Ecology and Management, 391, 184 - 193. 
Guo, K., Tao Z., Dejuan J., Cheng T., \& Hua Z. (2017). Variability of Yellow River turbid plume detected with satellite remote sensing during watersediment regulation. Journal of Continental Shelf Research, 135, 74-85.

Marfai, M.A., Rosaji, F.S.C., Cahyadi, A., \& Ghozali, M.R. (2014). Application of Unmanned Aerial Vehicle (UAV) for Shorline Anelysis. Paper in The 6th Indonesia Japan Joint Scientific Symposium (IJJSS) 2014.

Marfai, M.A., Rosaji, F.S.C., Cahyadi, A., \& Ghozali, M.R. (2014). Analisis Dinamika Pantai di Teluk Baron Menggunakan Teknologi Pesawat Tanpa Awak. Prosiding Pekan Ilmiah Tahunan Ikatan Geograf Indonesia (PIT IGI) 2014.

Masruroh, H., Sartohadi, J., \& Setiawan, A. (2016). Membangun Metode Identifikasi Longsor Berbasis Foto Udara Format Kecil di DAS Bompon, Magelang, Jawa Tengah. Majalah Geografi Indonesia, 30(2), 169 - 181.

Maulana, E., \& Wulan, T.R. (2015a). Pemotretan Udara dengan UAV Untuk Mendukung Kegiatan Konservasi Kawasan Gumuk Pasir Parangtritis. Simposium Nasional Sains Geoinformasi IV 2015: Penguatan Peran Sains Informasi Geografi dalam Mendukung Penanganan Isyu-Isyu Strategis Nasional.

Maulana, E., \& Wulan, T.R. (2015b). Pemetaan MultiRawan Kabupaten Malang Bagian Selatan dengan Menggunakan Pendekatan Bentangalam. Simposium Nasional Sains Geoinformasi IV 2015: Penguatan Peran Sains Informasi Geografi dalam Mendukung Penanganan Isyu-Isyu Strategis Nasional.

Neugirg, F., Stark, M., Kaiser, A., Vlacilova, M., Seta, M. D., Vergari, F., Schmidt, J., Becht, M., \& Haas, F. (2016). Erosion processes in calanchi in the Upper Orcia Valley, Southern Tuscany, Italy based on multitemporal high - resolution terrestrial LiDAR and UAV surveys. Journal of Geomorphology, $269,8-22$.

Niethammer, U., Jamer, M.R., Rothmund, S., Travelletti, J., \& Joswig, M. (2012). UAV-based remote sensing of the Super-Sauze landslide: Evaluation and results. Journal of Engienring Geology, 128, $2-11$.

Pineux, N., LIsein, J., Swerts, G., Bielders, C.L., Lejeune, P., Colinet, G., \& Degre, A. (2017). Can DEM time series produced by UAV be used to quantify diffuse erosion in an agricultural watershed? Journal of Geomorphology, 280, 122-136.

Purwanto, T.H. (2017). Pemanfaatan Foto Udara Format Kecil untuk Ekstraksi Digital Elevation Model dengan Metode Stereoplotting. Majalah Geografi Indonesia, 31(1), 73 - 89.
Putra, A. S., Maulana, E., Rahmadana, A. D. W., Wulan, T. R., Mahendra, I. W. W. Y., \& Putra, M. D.(2016). Uji Akurasi Foto Udara Dengan Menggunakan Data Uav Pada Kawasan Padat Pemukiman Penduduk (Studi Kasus: Kawasan Padat Sayidan, Daerah Istimewa Yogyakarta). Prosiding Seminar Nasional Pengindraan Jauh 2016. ISBN: 978-9791458-99-3

Rhee, J. \& Jungho I. (2017). Meteorological drought forecasting for ungauged areas based on machine learning: Using long-range climate forecast and remote sensing data. Journal of Agricurtural and Forest Meteorology, 237, 105-122.

Rozenstein, O. \& Jan A. (2017). A review of progress in identifying and characterizing biocrusts using proximal and remote sensing. International Journal of Applied Earth Observation and Geoinformation, 57, 245 - 255.

Stumpf, A., Malet, J. P., Kerle, N., Niethammer, U., \& Rothmund, S. (2013). Image-based mapping of surface fissures for the investigation of landslide dynamics. Journal of Geomorphology, 186, 1227.

Taubenbock, H., Standfus, I., Wurm, M., Krehl, A., \& Siedentop, S. (2017). Measuring morphological polycentricity - A comparative analysis of urban mass concentrations using remote sensing data. Journal of Computers, Environment and Urban Systems, 64, 42-56

Trigueros, C. R., Pedro A. N., Juan J., A., Johannes E. H., Margarita P., Sergio C., Peter D., \& Emilio N. (2017). Effects of saline reclaimed waters and deficit irrigation on Citrus physiology assessed by UAV remote sensing. Journal of Agricultural Water Management, 183, 60 - 69

Vetrivel, A., Markus G., Norman K., Francesco N., \& George V. (2017). Disaster damage detection through synergistic use of deep learning and 3D point cloud features derived from very high resolution oblique aerial images, and multiplekernel-learning. IPRS Journal of Photogrametry and Remote Sensing. https://doi.org/10.1016/j. isprsjprs.2017.03.001.

Watanabe, Y. \& Kawahara, Y. (2016). UAV photogrammetry for monitoring changes in river topography and vegetation. 12th International Conference on Hydroinformatics (HIC) 2016. Procedia Enginering, 154, 317-325 